Review article

\title{
Guidelines to cell engineering for monoclonal antibody production
}

\author{
A. Rita Costa, M. Elisa Rodrigues, Mariana Henriques *, Joana Azeredo, Rosário Oliveira \\ IBB - Institute for Biotechnology and Bioengineering, University of Minho, Braga, Portugal
}

\section{A R T I C L E I N F O}

\section{Article history:}

Received 17 June 2009

Accepted in revised form 19 October 2009

Available online 22 October 2009

\section{Keywords:}

Monoclonal antibody

Mammalian cells

Cell engineering

Transfection methods

Vector design

Clone selection

Cell adaptation

Productivity enhancement

\begin{abstract}
A B S T R A C T
Monoclonal antibodies (mAbs) are currently used for many diagnostic and therapeutic applications. The high demand for these biopharmaceuticals has led to the development of large-scale manufacturing processes, with productivity improvements being mainly achieved by optimization of bioreactor systems. However, more recently, the early steps of production, previous to bioreactor culture, have been presented as alternative areas where productivity enhancements can be achieved. Thus, this review describes the progress made for the improvement of productivity in mammalian expression systems for the high production of mAbs. Advances in the development of mAb-producing cell lines are being made, particularly regarding expression vector design and methods used for transfection, with the intent to create a reproducible methodology. Selection of the most suitable clones is also a critical step that can be improved, by including variables other than the expression level, which is still the common practice. Furthermore, strategies of cell engineering, although still mostly based on trial-and-error experimentation and not in standard protocols, hold great interest to improve cell growth and productivity, as well as product quality in the future. Improvements of the initial steps of the production process would not only result in cells with higher expression ability, but would also speed-up the process development.
\end{abstract}

(C) 2009 Elsevier B.V. All rights reserved.

\section{Introduction}

The number of monoclonal antibodies (mAbs) currently used in clinical trials and already approved for therapeutic applications has increased significantly in recent years [1-3]. They are currently used in the treatment of cancer, autoimmune disorders, allergic diseases, transplantation and anti-idiotype vaccine, among others [4].

The development of improved production of mAbs and other recombinant proteins is often associated with progress in cell culture technology and particularly in mammalian cell culture. The production of mAbs in mammalian cells consists of a long process that involves steps of transfection of the gene of interest into the cells, selection of clones, adaptation to different culture conditions (usually suspension and serum-free medium), culture in bioreactors and scale-up to industrial level. Indeed, due to the high demands for mAbs, a large-scale process needs to be established, with levels of production that meet the market needs (several $\mathrm{kg} /$ day) $[5,6]$. For this, the optimization of mAb production is usually performed in bioreactors, by testing different bioreactor modes of operation and culture parameters. However, even in the earlier steps of production, previous to scale-up, several variants are in play, influenc-

\footnotetext{
* Corresponding author. IBB - Institute for Biotechnology and Bioengineering, Centre of Biological Engineering, University of Minho, 4710-057 Braga, Portugal. Tel.: +351253604 408; fax: +351253678986.

E-mail address: mcrh@deb.uminho.pt (M. Henriques).
}

ing the final results of $m A b$ production. In fact, it is known that several parameters such as cell line type, cell size and cell cycle [7], product characteristics, vector/promoter of transfection $[8,9]$, methods of transfection and clone selection, post-transcription regulation [10] and growth medium, among many others, have great impact on the final productivity levels obtained. Therefore, the optimization of $\mathrm{mAb}$ production should start in the first few steps of the process, and not only during bioreactor culture.

The present goal is to outline the advances that have been made in $\mathrm{mAb}$ optimization, pre-scale-up processes its major achievements, and problems and limitations encountered that still need to be surpassed as well as the areas that hold major interest for future research.

\section{Expression system}

As already mentioned, mammalian cells are currently the main hosts for commercial production of therapeutic proteins, including mAbs [11-14]. Indeed, although a variety of either prokaryotic or eukaryotic (insect $[15,16]$ and plant cells $[17,18]$ ) systems have been used [19], the fact that mammalian cells have the ability to perform correct (human-like) post-translational modifications [20] makes them the most suitable system.

Production of mAbs in these cells necessarily begins with the development of a suitable cell line, determined by the selection of cell type. In order to be apt for biopharmaceutical application, cells must have the following characteristics: (i) support high-level 
product expression over long periods of time maintaining high viable cell density and genetic stability; (ii) be scalable; (iii) have appropriate abilities for post-translational processing and (iv) allow appropriate characterization for human safety [4]. Apart from these features, there is no restriction on the type of cell used [4], and several mammalian cell lines have been reported for achieving successful results (expression levels on the order of $10-100 \mathrm{pg} /$ cell/day) $[4,14]$. Furthermore, the choice of the best suitable cell line may also depend on the product application.

If the aim is to produce small-scale quantities of mAbs, as for preliminary investigation (biochemical and biophysical) analysis, then African green monkey kidney (COS) cells may be appropriate [19]. Indeed, they have been used for transient expression of active antibodies since 1987 [21,22]. However, they are not the most suitable cells for large-scale processes of production, since they lose the production ability over time. Actually, if the aim is large-scale production, the most currently used cells for this application are Chinese hamster ovary ( $\mathrm{CHO}$ ) cells, which have assumed an increasing importance both in laboratory $[21,23]$ and biopharmaceutical high-level mAb production $[13,14,20,24,25]$. Their suitability for large-scale and stable production of mAbs is related to their advantages of safety for use in humans $[11,19]$, resemblance between glycan structure of their product with the natural human $\mathrm{mAb}[11,26]$, ease of transfection, presence of a powerful gene amplification system, ease of adaptation to growth in suspension [27] and serum-free medium, and the ability to grow at high densities [11,19].

Other cells commonly used for large-scale production are myeloma cells [13,14,28-30], such as SP 2/0, YB 2/0, NS0 and P3X63.Ag8.653 [28]. Similar to CHO cells, they are able to grow at high densities, in suspension culture and serum-free medium, and are readily transfected [19]. Although recently their use has become less frequent, there are at least four Food and Drug Administration (FDA)-approved mAb drugs produced by these cells (specifically, Sp2/0-derived cell lines) - Remicade ${ }^{\circledast}$, ReoPro $^{\circledast}$, Simulect $^{\varpi}$ and Erbitux [31].

Hybridoma cells were also commonly used for mAb production for several decades [32,33]. However, their sensitivity to environmental changes [34,35] and toxic compounds formed during cell growth [36,37], as well as to shear and bubble damage in bioreactors [3], which complicate their large-scale culture, have reduced the application of these cells.

Interest in other cell lines for $\mathrm{mAb}$ production has risen, such as baby hamster kidney (BHK) [38,39], human embryonic kidney (HEK-293) [39,40] and human retina-derived PER-C6 cells $[41,42]$. This last cell line has recently been reported to produce significant levels of recombinant products, including mAbs, in a stable manner, being easily adapted to different growth conditions, not requiring gene amplification (thus providing rapid clone generation) nor adding non-human glycan structures to proteins $[41,43]$.

As demonstrated, a variety of cell lines can be used for mAb production, although not all have the ability to achieve high-level of expression. However, the levels of expression appear to be more dependent on the combination of host cell, expression vector, transfection and selection strategy, rather than on only the characteristics of the host cell $[4,29]$.

\section{Transfection}

After the selection of the most suitable cell type for the application intended, cells are transfected to obtain mAb-producing clones. Transfection is the introduction of the product DNA into the cells and involves different steps, from the design of the expression vector and the definition of the transfection method (expression system and DNA delivery system) to the selection of the transfected cells with the most desirable characteristics.

\subsection{Expression vector}

The expression of heterologous proteins in mammalian cells requires the use of specialized vectors $[44,45]$ to transfer the product gene into the cells [45]. These vectors should display three main features: expression levels independent from the site of integration in the genome, expression levels correlated with the number of integrated transgene copies and maintenance of expression efficiency over time [46]. Due to these requirements, mammalian vectors are usually plasmids. Plasmids are circular DNA molecules that exist in bacterial cells apart from their main chromosome and possess at least one replication origin [45]. This allows plasmids to replicate within cells, independently from bacterial or eukaryotic chromosomes [45]. The ability to express genes in mammalian cells requires a cassette that consists of two types of elements: promoter/enhancer elements that drive mRNA transcription and sequences that help to stabilize or enhance translation of the primary transcript [4].

Promoters/enhancers: promoters are elements that drive the expression of the recombinant gene, promoting and accurately positioning the beginning of transcription, while enhancers are elements that augment transcription [4,47]. For the expression of recombinant proteins in mammalian cells, a strong viral promoter/ enhancer or a cellular promoter/enhancer combination known to be particularly active to a certain host cell are commonly used $[4,45,47]$. The two elements most widely used are derived from the simian virus 40 (SV40) $[48,49]$ and cytomegalovirus (CMV) $[50,51]$. Nevertheless, other sequences are available for rodent-derived cell lines, such as myeloproliferative sarcoma virus (MPSV) [52], Rous sarcoma virus (RSV) [53], visna virus [54] and CHO elongation factor-alpha (EF1- $\alpha)[45,55]$.

Elements that stabilize and enhance translation of the primary transcript: different elements have been used for this effect, including polyadenylation signals, Kozak sequence and intervening sequences. Polyadenylation signals derived from SV40 [48] and bovine growth hormone gene [56] are the most commonly used in mammalian expression cassettes and are thought to prolong the half-life of mRNA in cytoplasm and to enable efficient translation [57]. The Kozak sequence is the optimum consensus sequence for surrounding the initiator codon of mammalian genes and is used to improve the translational initiation of mRNA of the gene of interest [58,59]. Intervening sequences consist of introns that are usually included in the mammalian expression vector. In most cases, the gene of interest is isolated as a cDNA without introns [27]; however, the inclusion of at least one intron between the promoter and the cDNA coding sequence can result in more efficient cytoplasmatic transport and higher steady state levels of cytoplasmatic mRNA available for translation [27,57].

When the mammalian expression vector is used for generation of a stable producing cell line, an extra sequence, encoding a selectable marker gene, is used. This selection gene can be present on the same vector as the recombinant gene or in separate vectors, and can be driven from a weak promoter, in order to increase the possibility to obtain high level of producer cells [27]. This usually reduces the efficiency of stable transfection, with decreased numbers of surviving cells, but those that survive selection have the ability to produce higher quantities of the recombinant product (for further details see next topic) [27].

Furthermore, to improve the efficiency of stable transfection, plasmids can be linearized before this process [60] using restriction enzymes [45]. Nevertheless, supercoiled plasmid DNA molecules will also be converted into linear molecules within the 
nucleus after 1-2 h [60]. Either way, the plasmid DNA molecules will be randomly integrated into the host genome. This random integration is simple and straight forward, but lacks reproducibility [46]. Indeed, it has been shown that the site of integration mostly influences the transcription rate of the recombinant gene, a phenomenon known as the position effect [27,61]. Depending on the surrounding chromatin at the integration site, expression of the product can be high, low or even null [27]. Furthermore, the expression of the recombinant gene tends to be inactivated (silenced) over time $[27,46]$. Consequently, the selection of suitable high-producing clones becomes tedious and time-consuming [27]. To overcome the position effects, different strategies have been developed [62-64]. Examples of these strategies include the use of anti-repressor elements flanking the vectors (i.e. expression augmenting sequence elements - EASE) [62], the integration of vectors specifically into chromosomal loci with open chromatin (highly transcribed) [63] or the use of nuclear regulatory factors (matrix-attachment regions (MARS) or scaffold-attachment regions (SARS)) [64,65].

There are situations where a stable and continuous production is not desired and a regulated or induced gene expression is needed [4]. For this purpose, inducible mammalian expression systems have been developed. Initially, they relied on inducers with pleiotropic effects on host cells, such as heat shock induction of expression with its promoter, heavy metal induction of the metallothionein promoter or glucocorticoid induction of steroid responsive promoters $[66,67]$. However, due to the broad range of effects that they produced and the high basal expression, new inducible systems have been developed, including the Lac/IPTG [68], the tetracycline (tet) [69,70], the streptogramin [71] and the ecdysone [72] systems. All these systems use a regulatory plasmid for the expression of a repressor or trans-activator and an expression plasmid containing the regulated promoter linked to the product gene [4]. The activity of the repressor or activator is regulated by the addition of a compound to the culture medium, controlling the promoter and, consequently, the expression of the gene of interest [4].

Apart from the problems in the design of expression vectors, that are common for all recombinant proteins, mAbs have additional issues that need to be considered. Indeed, their structure of heavy (HC) and light (LC) chain subunits, whose interaction influences the kinetics of $\mathrm{mAb}$ assembly [73], results in the need to express these subunits at optimal stoichiometric ratios (of equal extent) $[73,74]$. This has led to the development of different strategies of vector design [4], with the most common consisting of the use of two vectors, one for each chain, which are co-transfected into the cells $[74,75]$. Their relative expression is controlled by the proportion of each gene used in the co-transfection cocktail. Nevertheless, this control is not accurate [76,77], and this approach is considered to be the least efficient to obtain a balanced expression of both chains, since the site of integration has a major effect on recombinant gene expression [27]. Indeed, cell-to-cell variations of gene expression have been detected in the co-transfected cell pool [78]. Alternatively, a single vector using two identical promoters, one for each chain, can be used; however, this introduces a risk of recombination events [73]. For a more accurate control of the relative expression of multiple genes across a transfected cell pool, a single vector containing multiple compatible inducible promoters (i.e. cyclin E, cdc2, cyclin B1 and aurora A promoters), with each gene under the control of one independent promoter, can also be used $[79,80]$. This allows the introduction of an equal amount of different genes into each cell [81]. Moreover, by changing the concentration of the corresponding chemical inducers, it is possible to alter simultaneously the expression level of different genes (up to five genes, with the currently available inducible promoters) [8183].
In cases where chemical inducers are not desirable, the use of constitutive promoters with variable strengths offers an alternative approach [79]. Nevertheless, due to the lack of promoters with different strengths, this alternative narrows the range of expression levels that can be obtained [83]. The development of synthetic promoters could widen this range, but their application would probably be cell-line specific $[84,85]$.

Although a single vector system has the advantage of assuring equal introduction of genes into cells, the randomness of their integration into the cell genome remains a problem that results in inaccurate control of the relative expression of these genes [86].

\subsection{Transfection methods}

The introduction of the desired product gene into the host mammalian cell can be performed by a diversity of methods and systems, in a transient or stable way, whose choice is again dependent on the application intended, as well as economic and technical factors.

\subsubsection{Transient versus stable gene transfection}

Production of mAbs in mammalian cells for clinical or commercial purposes is usually done by stable transfection [27]. With the stable transfection technology, it is possible to obtain a continuous expression of the product by mammalian cells over prolonged periods of time [4]. Ultimately, this allows the delivery of larger quantities (kg/year) of protein from cells [87].

A stable transfection is accomplished by the integration of the DNA of the product gene into the genome of the host cell [4]. To guarantee the integration, a marker gene is usually transfected in conjunction with the gene of interest, and the transfected cells (producing the $\mathrm{mAb}$ ) are identified and selected by the characteristic provided by the product of the gene marker. This is, however, a labor-intensive and time-consuming step that involves considerable investment of resources/equipment $[4,87]$. Therefore, the need for quicker and more economical approaches for $\mathrm{mAb}$ production is evident [87] and can be provided by transient transfection. Although very similar, stable and transient transfection can be distinguished by the elimination of the steps of identification and selection of cells that have integrated the plasmid into the genome in transient transfection. This results in a faster process for obtaining mAb-producing cells. Since the product DNA is maintained/ replicated as an extrachromosomal unit [4], the expression ability is rapidly lost, only allowing the production of small (milligram to gram) quantities of mAbs $[4,88]$. Therefore, transient expression systems are not yet suitable for large-scale production but are very useful for high throughput screening in drug discovery processes, in vivo evaluation and early product analysis $[4,87,88]$. Moreover, it can be used with several cell lines (for example, COS [89], HEK-293 [39,40], CHO [90] and BHK [40]).

Due to the divergence between stable and transient systems in terms of plasmid insertion into the genome, the factors influencing the overall expression level of the transfected cells also differ. For transient systems, the efficiency of transfection is one of the most important factors, consisting in the percentage of cells taking-up and expressing DNA. On the other hand, in stable systems, the frequency of DNA integration into the chromosome (copy number) and the position of integration become more important [4]. Nevertheless, for both systems, the expression levels are strongly affected by the strength of the promoter driving the expression of the product gene $[4,88]$.

3.2.1.1. Gene marker for stable transfection. As mentioned above, for stable transfection, a marker gene is usually transfected with the gene of interest, conferring a selective advantage to the host cells 
[27]. The most commonly used marker genes are the dihydrofolate reductase (DHFR) and the glutamine synthetase (GS) [23,27,29].

The DHFR expression system, commonly used with CHO cells [91], is based on the dhfr gene coding for the DHFR enzyme, which is involved in nucleotide metabolism [27], catalyzing the conversion of dihydrofolate to tetrahydrofolate [92]. In this system, the selective advantage given to the transfected cells is the resistance to geneticin. Therefore, selection is performed by culturing the cells in medium lacking hypoxanthine and thymidine $(\mathrm{H} / \mathrm{T})$ [27] and containing geneticin [92]. Furthermore, this system allows a process of gene amplification that ultimately increases the cell capacity of production, by the use of methotrexate (MTX), a drug that inhibits the DHFR enzyme. Using increasing concentrations of MTX, transfected cells containing the dhfr gene will have to increase their capacity for DHFR synthesis, by amplifying the dhfr gene [14,92], in order to survive. As the amplification unit is much larger than the size of the dhfr gene, the gene of interest that is located in the same expression vector as the dhfr gene or adjacently resides in the host chromosomal DNA is co-amplified [93].

In contrast, the GS system ${ }^{\mathrm{TM}}$ (Lonza) exploits the glutamine metabolism in mammalian cells. Glutamine formation in mammalian cells follows an enzymatic pathway of biosynthesis from glutamate and ammonium using the GS enzyme [94]. Without glutamine in the growth medium, this GS enzyme is essential for the survival of mammalian cells in culture $[27,94]$. Since some cell lines, such as mouse myeloma lines [29], do not express sufficient GS to survive, it is possible to use a transfected GS gene as a selectable marker by permitting growth in a glutamine-free medium $[28,94]$. Cell lines that express sufficient GS to survive (i.e. CHO cell lines) can also be used with the GS system [95] by the application of methionine sulphoximine (MTS), an inhibitor of the endogenous GS activity [94]. Thus, only the transfectants with additional GS activity (i.e. the GS gene) are able to survive [94]. MTS also allows gene amplification using increasing levels of this toxic drug, such as the MTX in the DHFR system.

The GS system has a time advantage over the DHFR system during development, and requires fewer copies of the recombinant gene per cell [96], allowing a faster selection of high-producing cell lines [94]. Currently, there are over 50 products in clinical trials [94] and two human therapeutic mAbs (Zenapax (Roche) and Synagis $^{\infty}$ (Medimmune) that use the GS system [28].

Apart from these two traditional gene markers, other expression systems for transfection have been developed, such as the OS$\mathrm{CAR}^{\mathrm{TM}}$ system from the University of Edinburgh. This system is based on a series of partially disabled minigene vectors that encode for hypoxanthine phosphoribosyltransferase (HPRT), essential for purine synthesis via the normal cellular salvage pathway [97]. HPRT-deficient mammalian cells transfected with one of these minigenes along with the gene of interest are placed in a selective Hypoxanthine Aminopterin Thymidine (HAT) medium that blocks de novo purine synthesis. Consequently, cell survival becomes dependent on the salvage pathway using a disabled HPRT enzyme, and only the transfected cells are able to grow. Furthermore, since large amounts of the disabled HPRT enzyme are required for cell survival, gene amplification occurs. This implies that selection and amplification occur in a single step, providing a time advantage of the OSCAR ${ }^{\mathrm{TM}}$ system over both DHFR and GS systems that require multiple rounds of amplification after selection. Apart from being quicker, this expression system has also been shown to achieve higher expression yields, with lower costs of goods, due to the absence of the specialized media and toxic chemicals needed for the more traditional systems. Moreover, the high yields of protein production that have been obtained with $\mathrm{OSCAR}^{\mathrm{TM}}$ have shown to be stable [12]. Nevertheless, this system still needs to be further evaluated on its applicability for a wide range of cell types, media, scalability and bioreactor cultures.

\subsubsection{DNA delivery systems}

For the introduction of the gene of interest (and the marker gene in stable transfection) into mammalian cells, several DNA delivery systems have been developed, with non-viral gene transfer approaches being the most suitable for manufacturing purposes [27]. These methods include calcium-phosphate precipitation, electroporation, lipofection and polymer-mediated gene transfer [98-101]. It is impossible to evaluate whether any of these methods is better than the others because comprehensive and comparative studies are still lacking [27].

3.2.2.1. Calcium-phosphate precipitation. Although many methods have been developed for transferring plasmid DNA into cells to generate recombinant cell lines, calcium-phosphate co-precipitation $\left(\mathrm{CaPO}_{4}\right)$ remains one of the most widely used [102]. This method, first described in 1973 by Graham et al. [98], is based on the formation of a fine DNA precipitate or complex that enters mammalian cells via an endocytic vesicle [98,103] and has the advantages of being inexpensive and working in a wide range of cell types [4].

However, the efficiency and reproducibility of this method is low, and several strategies have been studied to improve the methodology. These include post-transfection treatments with dimethyl sulfoxide (DMSO), glycerol or chloroquine [103], to support the transfer of a high plasmid copy number into cells, resulting in increased transient and stable mAb production [102,104].

Nevertheless, the still low efficiencies of this method, the requirement of serum in the medium during transfection [105], as well as the high variability of the transfection outcome depending on minor alterations in procedure (relative concentrations of reagents and DNA) or environment ( $\mathrm{pH}$, temperature) [4], has led researchers to find better gene transfer methods [105].

3.2.2.2. Electroporation. Electroporation is a simple and rapid method used for gene delivery into cells [4,92]. This is accomplished by a pulsed electric field that disrupts the voltage gradient across the plasma membrane, creating reversible pores that allow the entry of DNA into the cell [106]. Though it is less cell type specific than other transfection methods, parameters like peak voltage and fall time of the discharge waveform need to be optimized in each case [4]. Furthermore, this method usually results in lower post-transfection cell viability [4]. Consequently, this method is more commonly used in small assays that require rapid and low levels of production.

3.2.2.3. Lipofection and polyfection. Lipofection and polyfection are the most recent, and probably most simple, transfection methodologies for gene delivery in a diversity of cells [4].

Lipofection consists of cationic lipid-mediated gene transfer into the cell, where cationic liposomes form a complex with the negatively charged DNA [4]. This method can be performed in the presence or absence of serum, with little or no toxicity [4], as well as with attached and suspended cells [87]. However, the amount of DNA and lipid used as well as the ratio between them affect transfection efficiencies and therefore still need to be optimized [107].

Polyfection, for its turn, refers to gene transfer mediated by cationic polymers (such as polycation polyethylenimine, PEI $[108,109]$ ) and dendrimers [4]. They interact with DNA forming a polyplex that protects DNA from degradation before reaching the cell nucleus [110]. This method can be used for gene delivery in serum-free suspension cultures $[108,109]$. As with lipofection, the optimal protocol needs to be empirically determined for each cell culture [4].

Although several methods have been developed for cell transfection, it is obvious that much work is still to be done. It has been 
suggested that the method delivering the highest number of plasmids into cells is also the one generating cell lines with the highest specific productivity [105]. However, the methods mentioned do not control the amount of functional plasmid that enters the cell nucleus, thus limiting the reproducibility of the generation of high-producing cell lines [105].

Furthermore, it would be important to reduce the need for empirical optimization of the transfection method for each cell line used, granting time and cost savings. This would be possible by the ideal development of a non-cell-specific method for the achievement of high-expression levels.

\subsection{Selection}

Cells transfected are subjected to a process of screening/selection that lasts from growth recovery after transfection, through single-cell cloning, amplification, suspension and serum-free adaptation, until final clone selection [111].

After transfection, mAb-producing cells are selected by being subjected to specific culture conditions that only allow survival and growth of cell clones expressing the marker gene product [44]. These clones are transferred as single cells to a second cultivation vessel, where the cultures are expanded to produce clonal populations [27]. Clones are then evaluated in terms of growth and product $(\mathrm{mAb})$ titer, and the highest producers are selected for another round(s) of cultivation and analysis, to confirm whether the levels of productivity are maintained [27,111].

These initially selected clones have a productivity that may not be optimal. To improve this, and as mentioned previously, cells can be subjected to repetitive rounds of exposure to higher concentrations of inhibitors of selective markers (MTX, MTS), which results in gene amplification [4,111]. The gene of interest expressing the antibody may be co-amplified with the selective marker gene, resulting in enhanced expression levels and mAb productivity $[4,111]$.

Traditionally, amplification is performed by the limiting dilution approach and is a time- and labor-consuming screening process. Indeed, the screening and selection of a highly productive and stable clone in a short time frame is still currently a major challenge [111]. Furthermore, due to the high workload it represents, the selection is made based solely on one feature - the expression level. However, other specific cell properties may also be important for the production process and should be included in the screening, such as, the ability of a clone to grow in serumfree medium, resistance to apoptosis, cell characteristics (i.e. cell size has been considered the major cellular determinant of productivity [112]), production kinetics suitable for the type of process used, stability of product formation and a general robustness of the cell line under the stress and shear conditions found in bioreactors [113]. Particularly, it is important that the level of mAb production of the selected clones remains stable for long periods of time [96,97], since the scale-up of the culture process to industry levels takes significant time. Generally, production levels should remain stable for at least 60 generations beyond production of a manufacturer's Working Cell Bank [96,113]. In the presence of the drug selective pressure (i.e. MTX and MTS), the production levels are usually stable $[29,96]$. However, due to the toxicity, high costs and complicated downstream purification associated with these drugs, it would be important to guaranty stability of production without their use $[27,97,111,113]$. Studies have shown that in the absence of drug selective pressure, there are signs of instability, with decreasing levels of production [23,96,114], which is often attributed to loss of recombinant gene copies during long-term culture [114]. To this end, it would be valuable, in terms of both time and costs, to identify molecular markers that could predict clone instability, eliminating the need for prolonged culture to confirm long-term stability [97]. Since the site of insertion of the prod- uct gene in the cell genome is known to affect stability of production, studies on the exact site of insertion, for example, using fluorescent in situ hybridization (FISH), may be very useful to identify specific regions of the genome associated with stability of recombinant gene expression [97].

Furthermore, other efforts are being made to generate a faster and simpler method of screening, including characteristics other than the expression level of cells. Techniques of flow cytometry and high-speed fluorescence-activated cell sorting (FACS) have been applied $[115,116]$ with relative success. These techniques rely upon microdrop methodologies [117,118], labeled anti-Fc antibody [119], metallothionein green fluorescent protein (GFP) fusion [120] or surface affinity matrix strategies to capture secreted antibody, prior to clone isolation [121-123]. One of these techniques is the Single Cell Secretion Assay developed by Borth et al. [123] that measures the specific production rates of individual cells by catching the secreted product in an artificial affinity matrix applied to the surface of viable cells, that was shown to reduce the workload required to isolate high producers during gene amplification by a factor of 10 . This method, followed by flow cytometry cell sorting combined with culture conditions that bring out a desired cell property was shown to allow the selection of rare cells with high production rates, non-growth associated production kinetics and improved stability in the presence of selective pressure [113].

Multiparameter FACS in association with dual intracellular autofluorescent reporter proteins (i.e. GFP) has also been described by Sleiman et al. [124] to accelerate selection and characterization of clones. The application of chain-specific reporter pairs using two-color intracellular fluorescence by FACS in identifying highantibody-producing clones provides an attractive alternative to single-color immunocytochemical methods of detection [124]. This technique eliminates the need for complex preparative steps or labor-intensive workflows and was shown to allow a 38-fold increase in $\mathrm{mAb}$ production, within 12 weeks, after only one single round of FACS [124].

Another approach used to accelerate clone selection involves the use of miniaturized bioreactors or shake flasks to simulate the standard production bioreactor conditions [111]. After adaptation of cells to growth in suspension and serum-free medium, an enriched medium similar to the final production medium and a similar feeding regime can be applied [111]. Thus, the clones more suitable for maintenance of high-producing levels in these bioreactor conditions can be selected.

\section{Cell engineering}

In recent years, continuous efforts have been made for the application of genetic engineering approaches to improve the utility of mammalian host cells in recombinant protein production. These techniques are used in an attempt to modify specific features of the host cells in order to enhance the protein yield as well as the quality $[4,11,14,125]$. Specifically, manipulations have been directed primarily at controlling cell growth, preventing cell death, promoting post-translational protein processing and folding [14] or enhancing the ability to grow in nutritionally defined media $[126,127]$. To achieve this, strategies of anti-apoptosis, metabolic engineering, engineering cells for hypothermic growth, as well as engineering of molecular chaperones and post-translational processing have been approached.

\subsection{Anti-apoptosis}

Anti-apoptosis engineering has been one of the main areas of research in the field of cell line development for protein production $[4,11,128]$. Mammalian cells are sensitive to their environment, 
and under stressful situations, such as nutrient deprivation, growth factor withdrawal, oxygen limitations, toxin accumulations, osmolarity decreases and excessive shear-stress levels, programmed cell death (apoptosis) is induced [14,128-131].

Therefore, it is of considerable value to be able to down-regulate or prevent apoptosis in culture in order to increase the density of viable cells by suppressing cell death, resulting in extended culture lifespan, and to increase the cell-specific productivity by maintaining the cellular activity. This will, ultimately, enable the maximization of the volumetric productivity of therapeutic proteins $[11,14,125,132]$.

Different anti-apoptotic strategies have been studied $[11,133,134]$. Among them, non-genetic approaches are the easiest to implement in existing cell culture processes. They rely on delaying the onset of apoptosis, by periodic nutrient feeding after determining the time at which nutrients are depleted [11], the use of galactose instead of glucose as a carbon source [133], or the use of nucleosides such as adenosine [134].

Another approach consists in the overexpression of anti-apoptotic genes that mammalian cells possess. Indeed, the process of cell death involves a series of biochemical steps with activation of pro-death factors and proteins inside the cells that lead to the inactivation of essential mechanisms for life [135]. However, mammalian cells also have genes encoding for anti-death proteins that prevent the activation of the apoptosis cascade [132]. By increasing the expression or activity of one or more of these anti-death proteins, it may be possible to enhance cell survival under stressful conditions [132]. The anti-apoptotic genes already tested, with positive results in terms of both cell density and protein titer are Bcl2 [130,136,137], Bcl-xL [130,136,138], 30Kc6 [125], Aven [132,139], XIAP [140], CrmA [141] and E1B-19K [132,142]. Furthermore, anti-apoptotic chemicals have also been used, such as suramin [143], N-acetylcysteine (NAC) [144] and silkworm hemolymph [145], offering protection against apoptosis under serum-free conditions [11].

As the cellular pathway leading to apoptosis involves the activation of members of caspases [146], the inhibition of caspase expression has also been tested as an anti-apoptosis strategy [147]. Specific caspase inhibitors have been tested, but their high cost for large-scale cultures might make them unaffordable [11]. Therefore, strategies of down-regulation of these caspases were tested, aiming primarily for caspase- 3 , since it plays a key role in apoptosis and is critical to cellular commitment to irreversible apoptotic cell death [148]. Silencing of caspase-3 using antisense technology $[149,150]$ and co-down-regulation of caspase-3 and caspase-7 [151] are some of the methodologies used. However, this down-regulation has shown to be beneficial only at times, because cells tend to compensate for the lack of some effectors by up-regulating others. Therefore, in caspase silencing, the interrelationship between molecules in a cell and the cell's competence to cope with changes needs to be considered [11].

Another strategy of anti-apoptosis is based on the inhibition of cell cycle progression. Indeed, control of progression through the cell cycle may significantly increase cell density and productivity in mammalian cell cultures $[4,152]$. It has been shown that there is a critical relationship between the emergence of cell death and cell cycle progression, further implying that conditions that support less than maximal passage through the cell cycle may protect cells against apoptosis [152,153]. Attempts made in this sense include modulation of $c$-jun [154], growing under glutamine limitation [131], inducible expression of p27 [70,136] and p21cip1 $[137,155]$, and use of rapamycin $[152,156]$. They result in slower progression through cell cycle, with reduced cell death (and increased viability), enabling viable proliferation to higher maximum viable cell densities and, therefore, increasing specific mAb production [152].
A combination of different strategies, or the use of multiple anti-apoptosis genes, can be favorable and improve protection against apoptosis, as it has been shown in some studies [137,139].

Furthermore, it has been suggested that the optimal anti-apoptosis strategy may involve lower level of expression of anti-apoptosis genes during the exponential phases of cell growth, followed by their overexpression during the post-exponential phase in which cells are subjected to more severe environment stresses [132]. Nevertheless, this control demands the development of inducible technologies that could be readily tuned to different expression levels and at the same time can be affordable and adaptable to scale-up for larger bioreactors [132].

\subsection{Metabolic engineering}

Another focus of genetic manipulation has been metabolic engineering as a way to indirectly increase cell growth and volumetric production, through the inhibition of the accumulation of toxic metabolic by-products, such as lactate and ammonia [4,11]. Two approaches are commonly used: improvement of the efficiency of central carbon (primary) metabolism and the reduction in lactate accumulation [4]. The first approach is usually based on redirecting cells into pathways using energy more efficiently [11], for example, overexpressing pyruvate carboxylase which increases the flux of glucose into the tricarboxylic acid cycle [157]. For the second approach, partial disruption of the lactase dehydrogenase A (LDHA) gene has been used $[37,158]$, as well as the overexpression of urea cycle enzymes, carbamoyl phosphate synthetase I and ornithine transcarbamoylase that reduce the accumulation of ammonium ions in the culture medium [159].

\subsection{Engineering cells for hypothermic growth}

Low temperature cultivation is a simple and very effective method of controlling cell proliferation [160]. It was observed that mammalian cells growing between $27^{\circ} \mathrm{C}$ and $32^{\circ} \mathrm{C}$ have a low specific growth rate, but maintain a high viability and reduced contamination by endogenous cell proteins [161,162]. Also, low temperature cultivation has been associated with increases in specific productivity $(q)[161,163,164]$. However, the increase in specific productivity observed at low temperature does not result in a similar increase in the volumetric productivity, due to the reduced cell growth rates [11]. In fact, an inverse relationship between cell-specific growth rate and specific productivity has been observed [161,165].

Consequently, genetic engineering strategies to improve volumetric recombinant protein production at low temperatures have been developed, yet with mixed and not so positive results $[11,166]$. These strategies focus on alleviating the growth suppression at low temperature and include down-regulation of coldinducible RNA-binding protein (CIRP) with the intent to boost growth properties at hypothermia $[24,167]$ and adaptation of cells to low culture temperature. However, although improving cell growth at low temperatures, neither attempt has proved to be efficient in increasing cell productivity [24,167].

Therefore, the molecular mechanisms associated with slow growth rate at lower culture temperature need to be further studied in order to be exploited as a tool for host cell engineering [11]. Nevertheless, it has been usually observed that high producer cell lines have slower growth rates due to the additional metabolic burden of production thrust on them [11].

Alternatively, a biphasic process, where cells are first cultivated at $37^{\circ} \mathrm{C}$ in the growth phase for high growth rates followed by a temperature shift to low culture temperature in the production phase for high productivity may be used to increase the volumetric productivity [164,168]. 


\subsection{Engineering of molecular chaperones}

Since mAbs are secreted proteins, and the endoplasmic reticulum (ER) has a quintessential role in the secretory pathway of cells, many studies have been done to understand the relationship between the production of $\mathrm{mAbs}$ and the regulation of ER proteins in the host cells [169]. It has been observed/suggested that the rate-limiting steps in protein expression may be translation or post-translational processes, since the amount of protein secreted does not increase proportionally with the gene copy number $[170,171]$. Some studies have demonstrated that the up-regulation of the ER proteins involved in protein secretion is associated with high-levels of protein production [169,172,173].

Therefore, there has been some interest in host cell engineering strategies targeting the secretory pathway, in order to enhance $\mathrm{mAb}$ production $[11,14,169]$. The most common approach involves the overexpression of ER chaperones, which has achieved varied results in mammalian cells $[11,169,174-176]$. Actually, it has been observed that the effects of molecular chaperones on protein production is dependent on several factors, including the expression system used, the target proteins and the chaperones concerned [11]. For example, protein disulfide isomerase (PDI) has been used for chaperone engineering, with its overexpression on protein-producing cell lines resulting in either enhanced [172,176,177], decreased [175] or even unaffected productivities [11,175]. When in combination with the heavy chain-binding protein (BiP), decreased productivity was observed [174]. Studies of single overexpression of BiP showed its relation to increased productivity $[172,173]$. However, in another study, it was the reduction in the level of BiP expression, rather than its overexpression, that resulted in improved productivity [178].

Other chaperones have also been tested, such as the overexpression of ERp57 [179], glucose regulated protein 94 (GRP94) [176] or endoplasmin [172], or even the simultaneous expression of lectin-binding chaperones, calnexin and calreticulin [180], which resulted in increased productivities.

Since the gene regulation system in mammalian cells is so complex, targeting single components of the secretory pathway in isolation may not be the best approach for increasing productivity $[11,169]$. Indeed, the overexpression of several chaperones, co-chaperones, holdases and/or foldases, concomitantly, in a functionally meaningful ratio to modulate the secretory machinery in a global fashion might be a better strategy [11]. A strategy for this global modulation may target the X-box-binding protein 1 (XBP$1 S)$, which is a regulator of multiple critical genes in the secretory pathway [169]. Ku et al. [169] demonstrated that the overexpression of the XBP-1S is not a strategy that indiscriminately enhances recombinant protein production, but one which is effective in relieving secretory bottlenecks that may be encountered in some production systems [169].

\subsection{Engineering of post-translational processing (glycosylation)}

While optimizing processes to achieve high yield, it is critical to monitor product quality changes at every stage of development. Glycosylation variation, which can impact in vivo mAb functions and stability, is one of the most sensitive quality-related attributes. Cell culture factors, host cell selection and protein specific features influence the glycosylation pathway, leading to the production of proteins with variable/suboptimal clearance or functionality $[4,181]$. In an attempt to achieve/guarantee a correct level of glycosylation on proteins produced in mammalian cell culture and to improve effector functions (such as antibody-dependent cell mediated cytotoxicity (ADCC) and complement-dependent cytotoxicity (CDC)), recent studies have focused on glycosylation engineering with specific manipulation of oligosaccharide structures [25,182].
This manipulation can be achieved by the overexpression of appropriate glycosyltransferases, either enhancing glycan quality, by increasing homogeneity of native structures, or introducing non-host cell residues to specialize glycan quality and function [4]. Examples of the former include the overexpression of galactosyltransferase (increase in the galactose levels), sialyltransferase (increase in the sialic acid levels) [183] and $\mathrm{N}$-acetylglucosaminyltransferase III (increase the fraction of bisecting $\mathrm{N}$-acetylglucosamine residues) [184]. The overexpression of $\mathrm{N}$ acetylglucosaminyltransferase III (GNTIII) can be achieved by transfecting cells with the GNTIII enzyme and results in nonfucosylated mAbs that have improved ADCC and CDC functions $[184,189,190]$. Non-fucosylated $m A b s$ can also be obtained using cells with $\alpha$-1,6-fucosyltransferase gene (FUT 8) knockout $[187,188]$.

For the second approach, examples include the introduction of sialic acid in an $\alpha-2,6$ linkage to glycoproteins synthesized by $\mathrm{CHO}$ and $\mathrm{BHK}$ cells that lack the specific sialyltransferase responsible for this transfer $[185,186]$.

New cellular engineering strategies to improve cell viability and productivity of recombinant pharmaceuticals are being developed. However, the current understanding of cellular and molecular constraints on the function of engineered mammalian cells in vitro is still very limited. So, this needs to be improved to allow the rational enhancement of a certain cell function (i.e. productivity), rather than the current trial-and-error approach [172,191].

It has been suggested that the most effective strategies for engineering cell culture performance in vitro need to rely on the specific knowledge of the system in question and on the use of quantitative data. Furthermore, these strategies should derive from validated predictive models and involve simultaneous modulation of the activity of different cell components [172]. Indeed, the next generation of cell engineering strategies should be multigenic in design and reproduce the multigenic control of cell function [192]. However, currently, there is lack of relevant data concerning the dynamic levels of the multiple discrete components of a mammalian system and an incomplete understanding of their interactions [193].

\section{Adaptation to new culture conditions}

The most common processes for large-scale production of biophamarceutical products, including mAbs, require suspended cells and also the use of serum-free medium. Therefore, after obtaining mAb-producing cells, they need to be subjected to a process of adaptation to these new conditions, which, nevertheless, can impose some limitations to the development of the process of production.

\subsection{Suspension}

Large-scale production of mAbs in bioreactors is usually performed with cells growing in suspension. This is because the surface/volume ratio in suspension cultures is much higher than in adherent cultures [4], allowing increased cell densities and productivities to be reached. However, most mammalian cells naturally grow adherently and their growth in suspension demands a process of adaptation. This adaptation is not possible to all cell types, which limits the choice of the cell line and can be very time-consuming [62].

Adaptation of cells that are grown adherently in serum-containing medium to growth in suspension is usually accomplished using the same medium but changing cells to spinner vessels [4], shake flasks [57,194] or even roller bottles [195], with agitation of 50$80 \mathrm{rpm}$ [4]. To guarantee a successful adaptation some parameters 
are critical, such as the initial inoculum density and viability. In a process of adaptation, there is usually a high proportion of cells that do not survive. Therefore, it is of extreme importance that the low proportion of survival cells is in sufficient number so that expansion does not take too long or becomes stalled. For this reason, the suspension culture should be initiated with a suitable high cell density. Furthermore, a strict monitoring should be maintained over the culture during the adaptation phase, with cell growth and viability evaluated frequently for several passages. Furthermore, productivity levels should also be assessed, since they can change during adaptation [4].

To ease the passage from adherent to suspension culture, two approaches can be followed: media optimization (for example, altering cation concentration) [192] and the use of specially treated glass and plasticware [4]. Also, since cells are subjected to constant mixing/agitation during suspension culture, shear-stress can be inflicted on cells. To minimize damage caused by agitation, shearprotectants such as Pluronic F68 are commonly used [13]. It should be mentioned that any additions to the culture have implications to downstream processing (purification) and, therefore, need to be thoroughly analyzed.

\subsection{Serum-free medium}

Serum is an essential component of any culture medium supporting cell proliferation. However, serum has many disadvantages for the production of human therapeutics, such as: (i) the variable concentrations of components between batches which jeopardize the process consistency; (ii) the burden put on downstream processing [196,197]; (iii) the high costs [196] and (iv) the risk of transmission of animal diseases to humans. Therefore, the use of serum-free (SF) or protein-free (PF) media is currently one of the main goals of commercial cell culture $[4,198]$. However, this requires the development of a specific medium for each cell line, since there is no universal SF medium [197].

Extensive efforts have been made in order to identify serumsubstituting supplements that fulfill the complex nutritional requirements of mammalian cells, which is usually done by timeconsuming methodologies $[199,200]$. These include the Ham's approach (gradual reduction in the concentration of undefined supplements in the culture) [201], the Sato's approach (reconstruction of the extracellular environment involved in supporting cell growth in vivo) [202], the top-down approach (taking of an existing serum-supplemented formulation for a similar cell line and selection of the constituents that are stimulatory for growth) and the bottom-up approach (selection of a basal medium, analysis of individual components for their effects on growth and combination of them to make a serum-free formulation) [4]. To overcome this, statistical experimental design can be used as an efficient way of screening large numbers of medium supplements and identifying the most important [203], in a time-efficient way, accelerating the process of SF media development. Furthermore, in the development of SF media for mAb production, components important for production (and not just cell growth) should also be considered.

Nevertheless, even with chemically defined SF media, cell adaptation to the new medium can be a long process, since it is not yet physiologically well understood and, therefore, more difficult to perform and more time-consuming [204] than adaptation of cells to suspension in serum-containing media [4].

For the adaptation to SF media, basically two approaches can be used: a direct approach, where serum is completely removed in a single step and a gradual/sequential approach, where serum concentration in the medium is slowly reduced [4]. In both approaches, cell growth occurs slowly, with low viabilities obtained for several passages, demanding constant monitoring [4]. Although there is still no easy way to accelerate the adaptation, the use of high inoculum densities [204,205], as well as media exchanges using centrifugation of cells and resuspension in fresh media (to remove waste products and to maintain an adequate seeding density) [4], can somewhat abbreviate the process. Furthermore, in some cases, during cell adaptation to SF medium, the selective pressure on the gene of interest must be reduced, so that cells can adapt more easily. However, even in lower concentration, the selective pressure should be maintained so that the high-level gene expression is preserved [4]. Also, it is interesting to note that SF adaptation can even be advantageous in terms of mAb production, as reported in several works that indicate significantly increased $\mathrm{mAb}$ production kinetics in SF medium with respect to those done in serum-containing medium [206,207].

\section{Conclusions}

The increasing importance of mAbs in therapeutic applications, occurring in recent years, has led to the rapid development of techniques/strategies for their large-scale production. Efforts continue on optimization of $\mathrm{mAb}$ production, but they usually focus on bioreactor design and/or operation. However, the procedures performed before bioreactor culture, such as transfection of the gene of interest into the cells, selection of the most appropriate clone and adaptation to different culture conditions, have been shown to strongly impact the expression levels possible to achieve in latter stages. Consequently, optimization should include and begin with these initial steps of creation of a mAb-producing cell line. Furthermore, these procedures are very time-consuming and, therefore, the ones most responsible for the delays observed until a mAb becomes commercially available. This is a major drawback for biopharmaceutical companies, whose success highly depends on how fast they can put their products in the market.

Studies made in this area show that cell engineering, in particular, holds a great potential to surpass the obstacles currently encountered. Indeed, developments in this field may allow a better control over cell growth and productivity, enhance their ability to adapt to new conditions, as well as increase the quality of the product obtained. However, some results have been contradictory, which can be related to the lack of knowledge about cellular mechanisms and specifically their interconnections. If the current know-how is not expanded, success will strongly depend on trial-and-error experiments, and progress in this field will be dependent on new discoveries and their application.

\section{References}

[1] G. Walsh, Biopharmaceutical benchmarks 2003, Nat. Biotech. 21 (2003) 865870.

[2] R.C. Das, Antibodies in biotech: year of the bear, Am. Biotechnol. Lab. 20 (2003) 4-6.

[3] S. Nilsang, K.S. Nandakumar, I.Y. Galaev, S.K. Rakshit, R. Holmdahl, B. Mattiasson, A. Kumar, Monoclonal antibody production using a new supermacroporous cryogel bioreactor, Biotechnol. Prog. 23 (2007) 932-939.

[4] S.S. Ozturk, W.-S. Hu, Cell Culture Technology for Pharmaceutical and Cellbased Therapies, CRC Press, New York, 2006.

[5] E. Jain, A. Kumar, Upstream processes in antibody production: evaluation of critical parameters, Biotechnol. Adv. 26 (2008) 46-71.

[6] R.C. Das, Proteins and antibodies make advances as therapeutic products, Am Clin. Lab. 20 (2001) 10-14

[7] H. Chai, M. Al-Rubeai, K.L. Chua, S.K.W. Oh, M.G.S. Yap, Insect cell line dependent gene expression of recombinant human tumor necrosis factor- $\beta$, Enzyme Microb. Technol. 18 (1996) 126-132.

[8] M.B. Gu, P. Todd, D.S. Kompala, Metabolic burden in recombinant CHO cells: effect of dhfr gene amplification and lacZ expression, Cytotechnology 18 (1995) 159-166.

[9] G.G. Banik, P.W. Todd, D.S. Kompala, Foreign protein expression from S phase specific promoters in continuous cultures of recombinant $\mathrm{CHO}$ cells, Cytotechnology 22 (1996) 179-184

[10] D.R. Lloyd, M. Al-Rubeai, Cell cycle, in: M.C. Flickinger, S.W. Drew (Eds.) Encyclopedia of Bioprocess Technology: Fermentation, Biocatalysis and Bioseparation, John Wiley and Sons, New York, 1999, pp. 465-476. 
[11] C.M. Mohan, Y.-G. Kim, J. Koo, G.M. Lee, Assessment of cell engineering strategies for improved therapeutic protein production in $\mathrm{CHO}$ cells, Biotechnol. J. 3 (2008) 624-630.

[12] D.W. Melton, A.-M. Ketchen, A.J. Kind, C. McEwan, D. Paisley, J. Selfridge, A one-step gene amplification system for use in cultured mammalian cells and transgenic animals, Transgenic Res. 10 (2001) 133-142.

[13] L. Chu, D.K. Robinson, Industrial choices for protein production by large-scale cell culture, Curr. Opin. Biotechnol. 12 (2001) 180-187.

[14] D.C. Andersen, D.E. Reilly, Production technologies for monoclonal antibodies and their fragments, Curr. Opin. Biotechnol. 15 (2004) 456-462.

[15] C.A. Hasemann, J.D. Capra, High-level production of a functional immunoglobulin heterodimer in a baculovirus expression system, Proc. Natl. Acad. Sci. USA 87 (1990) 3942-3946.

[16] R.B. Kirkpatrick, S. Ganguly, M. Angelichio, S. Griego, A. Shatzman, C. Silverman, M. Rosenberg, Heavy chain dimers as well as complete antibodies are efficiently formed and secreted from Drosophila via a BiPmediated pathway, J. Biol. Chem. 270 (1995) 19800-19805.

[17] S. Hellwig, J. Drossard, R.M. Twyman, R. Fischer, Plant cell cultures for the production of recombinant proteins, Nat. Biotech. 22 (2004) 1415-1422.

[18] R.G. Soderquist, J.M. Lee, Enhanced production of recombinant proteins from plant cells by the application of osmotic stress and protein stabilization, Plant. Cell Rep. 24 (2005) 127-132.

[19] J.J. Trill, A.R. Shatzman, S. Ganquly, Production of monoclonal antibodies in COS and CHO cells, Curr. Opin. Biotechnol. 6 (1995) 553-560.

[20] R.G. Werner, W. Noe, K. Kopp, M. Schlüter, Appropriate mammalian expression systems for biopharmaceuticals, Drug Res. 48 (1998) 870-880.

[21] L.A. Fouser, S.L. Swanberg, B.-Y. Lin, M. Benedict, K. Kelleher, D.A. Cumming, G.E. Riedel, High level expression of a chimeric anti-ganglioside GD2 antibody: genomic kappa sequences improve expression in $\mathrm{COS}$ and $\mathrm{CHO}$ cells, Nat. Biotech. 10 (1992) 1121-1127.

[22] M.S. Hayden, P.S. Linsley, M.A. Gayle, J. Bajorath, W.A. Brady, N.A. Norris, H.P. Fell, J.A. Ledbetter, L.K. Gilliland, Single-chain mono- and bispecific antibody derivatives with novel biological properties and antitumour activity from a COS cell transient expression system, Ther. Immunol. 1 (1994) 3-15.

[23] M.J. Page, M.A. Sydenham, High level expression of the humanized monoclonal antibody CAMPATH-1H in Chinese hamster ovary cells, Nat. Biotech. 9 (1991) 64-68.

[24] S.K. Yoon, J.K. Hong, S.H. Choo, J.Y. Song, H.W. Park, G.M. Lee, Adaptation of Chinese hamster ovary cells to low culture temperature: cell growth and recombinant protein production, J. Biotechnol. 122 (2006) 463-472.

[25] D.C. Andersen, L. Krummen, Recombinant protein expression for therapeutic applications, Curr. Opin. Biotechnol. 13 (2002) 117-123.

[26] C.F. Goochee, M.J. Gramer, D.C. Andersen, J.C. Bahr, J.R. Rasmussen, Frontiers, in: P. Todd (Ed.), Bioprocessing, vol. II, American Chemical Society, Washington, DC, 1992, pp. 198-240.

[27] F.M. Wurm, Production of recombinant protein therapeutics in cultivated mammalian cells, Nat. Biotech. 22 (2004) 1393-1398.

[28] L.M. Barnes, C.M. Bentley, A.J. Dickson, Advances in animal cell recombinant protein production: GS-NSO expression system, Cytotechnology 32 (2000) 109-123.

[29] C.R. Bebbington, G. Renner, S. Thomson, D. King, D. Abrams, G.T. Yarranton, High-level expression of a recombinant antibody from myeloma cells using a glutamine synthetase gene as an amplifiable selectable marker, Nat. Biotech. 10 (1992) 169-175.

[30] K. Shitara, K. Nakamura, Y. Tokutake-Tanaka, M. Fukushima, N. Hanai, A new vector for the high level expression of chimeric antibodies in myeloma cells, J. Immunol. Methods 167 (1994) 271-278.

[31] J.-D. Yang, C. Lu, B. Stasny, J. Henley, W. Guinto, C. Gonzalez, J. Henley, M. Fung, B. Collopy, M. Benjamino, J. Gangi, M. Hanson, E. Ille, Fed-batch bioreactor process scale-up from 3-L to 2500-L scale for monoclonal antibody production from cell culture, Biotechnol. Bioeng. 98 (2007) 141-154.

[32] G. Kohler, C. Milstein, Continuous cultures of fused cells secreting antibody of predefined specificity, Nature 256 (1975) 495-497.

[33] Y.-J. Tang, R. Ohashi, J.-F.P. Hamel, Perfusion culture of hybridoma cells for hyperproduction of IgG2a monoclonal antibody in a Wave bioreactorperfusion culture system, Biotechnol. Prog. 23 (2007) 255-264.

[34] E.B. Moran, S.T. McGowan, J.M. McGuire, J.E. Frankland, I.A. Oyebade, W. Waller, L.C. Archer, L.O. Morris, J. Pandya, S.R. Nathan, L. Smith, M.L. Cadette, J.T. Michalowski, A systematic approach to the validation of process contro parameters for monoclonal antibody production in fed-batch culture of a murine myeloma, Biotechnol. Prog. 69 (2000) 242-255.

[35] D.C. Andersen, T. Bridges, M. Gawlitzek, C. Hoy, Multiple cell culture factors can affect the glycosylation of Asn-184 in CHO-produced tissue-type plasminogen activator, Biotechnol. Prog. 70 (2000) 25-31.

[36] T. Hassell, S. Gleave, M. Butler, Growth inhibition in animal cell culture: the effect of lactate and ammonia, Appl. Biochem. Biotechnol. 30 (1991) 29-41.

[37] K. Chen, Q. Liu, L. Xie, P.A. Sharp, D.I.C. Wang, Engineering of a mammalian cell line for reduction of lactate formation and high monoclonal antibody production, Biotechnol. Bioeng. 72 (2001) 55-61.

[38] P.-A. Girod, N. Mermod, Use of scaffold/matrix-attachment regions for protein production, in: S.C. Makrides (Ed.), Gene Transfer and Expression in Mammalian Cells, Elsevier Science BV, Amsterdam, 2003, pp. 359-379.

[39] M. Jordan, C. Köhne, F.M. Wurm, Calcium-phosphate mediated DNA transfer into HEK-293 cells in suspension: control of physicochemical parameters allows transfection in stirred media. Transfection and protein expression in mammalian cells, Cytotechnology 26 (1998) 39-47.
[40] F. Wurm, A. Bernard, Large-scale transient expression in mammalian cells for recombinant protein production, Curr. Opin. Biotechnol. 10 (1999) 156-159.

[41] D. Jones, N. Kroos, R. Anema, B. Van Montfort, A. Vooys, S. van der Kraats, E. van der Helm, S. Smits, J. Schouten, K. Brouwer, F. Lagerwerf, P. Van Berkel, D.J. Opstelten, T. Logtenberg, A. Bout, High-level expression of recombinant IgG in the human cell line PER.C6, Biotechnol. Prog. 19 (2003) 163-168.

[42] D.H. Jones, P.H.C. van Berkel, T. Logtenberg, A. Bout, PER.C6 cell-line for human antibody production, Gen. Eng. News 22 (2002) 50.

[43] F.M. Wurm, A. Johnson, Y.S. Lie, M.T. Etcheverry, K.P. Anderson, Host cell derived retroviral sequences enhance transfection and expression efficiency in CHO cells, in: R.E. Spier, J.B. Griffiths, G. MacDonnald (Eds.), Animal Cell Technology: Developments, Processes and Products, ButterworthHeinemann, Oxford, UK, 1992, pp. 35-41.

[44] V. Chisholm, High efficiency gene transfer into mammalian cells, in: D.M. Glover, B.D. Hames (Eds.), DNA Cloning: A Practical Approach, Mammalian Systems, vol. IV, Oxford University Press, Oxford, 1995, p. 1.

[45] Ö. Özdemir, The construction of a mammalian transfection vector for expression of cytosine-5 specific DNA methyltransferase gene M.Msp1 in cultured cells, Turk. J. Biol. 22 (1998) 161-170.

[46] L. Blaas, M. Musteanu, R. Eferl, A. Bauer, E. Casanova, Bacterial artificial chromosomes improve recombinant protein production in mammalian cells, BMC Biotechnol. 9 (2009) 3.

[47] G. Ringold, B. Dieckmann, F. Lee, Co-expression and amplification of dihydrofolate reductase cDNA and the Escherichia coli XGPRT gene in Chinese hamster ovary cells, J. Mol. Appl. Genet. 1 (1982) 165-175.

[48] S. Carswell, J.C. Alwine, Efficiency of utilization of the simian virus 40 late polyadenylation site: effects of upstream sequences, Mol. Cell. Biol. 9 (1989) 4248-4258.

[49] Y. Gluzman, SV40-transformed simian cells support the replication of early SV40 mutants, Cell 23 (1981) 175-182.

[50] M. Boshart, F. Weber, G. Jahn, K. Dorsch-Hòler, B. Fleckenstein, W. Schaffner, A very strong enhancer is located upstream of an immediate early gene of human cytomegalovirus, Cell 41 (1985) 521-530.

[51] H.P. Rihs, D.A. Jans, H. Fan, R. Peters, The rate of nuclear cytoplasmic protein transport is determined by the caseinkinase II site flanking the nuclear localisation sequence of the SV40 T-antigen, EMBO J. 10 (1991) 633-639.

[52] F. Hilberg, C. Stocking, W. Ostertag, M. Grez, Functional analysis of a retroviral host-range mutant: altered long terminal repeat sequences allow expression in embryonal carcinoma cells, Proc. Natl. Acad. Sci. USA 84 (1987) 52325236.

[53] C.M. Gorman, G.T. Merlino, M.C. Willingham, I. Pastan, B.H. Howard, The Rous sarcoma virus long terminal repeat is a strong promoter when introduced into a variety of eukaryotic cells by DNA-mediated transfection, Proc. Natl. Acad. Sci. USA 79 (1982) 6777-6781.

[54] L.M. Carruth, B.A. Morse, J.E. Clements, The leucine domain of the visna virus Tat protein mediates targeting to an AP-1 site in the viral long terminal repeat, J. Virol. 70 (1996) 4338-4344.

[55] D. Allison, Development and use of CHEF1 vectors for rapid isolation of mammalian cell lines expressing high levels of recombinant proteins, Cell Culture Engineering VIII, Snowmass, CO, 2002

[56] W.L. Miller, J.A. Martial, J.D. Baxter, Molecular cloning of DNA complementary to bovine growth hormone mRNA, J. Biol. Chem. 255 (1980) 7521-7524.

[57] M.T.F. Huang, C.M. Gorman, Intervening sequences increase efficiency of RNA $3^{\prime}$ processing and accumulation of cytoplasmic RNA, Nucl. Acids Res. 18 (1990) 937-947.

[58] M. Kozak, Point mutations define a sequence flanking the AUG initiator codon that modulates translation by eukaryotic ribosomes, Cell 44 (1986) 283-292.

[59] M. Kozak, Adherence to the first-AUG rule when a second AUG codon follows closely upon the first, Proc. Natl. Acad. Sci. USA 92 (1995) 7134.

[60] G.K. Finn, B.W. Kurz, R.Z. Cheng, R.J. Shmookler Reis, Homologous plasmid recombination is elevated in immortally transformed cells, Mol. Cell. Biol. 9 (1989) 4009-4017.

[61] S.K. Eszterhas, E.E. Bouhassira, D.I.K. Martin, S. Fiering, Transcriptional interference by independently regulated genes occurs in any relative arrangement of the genes and is influenced by chromosomal integration position, Mol. Cell. Biol. 22 (2002) 469-479.

[62] T.H.J. Kwaks, P. Barnett, W. Hemrika, T. Siersma, R.G.A.B. Sewalt, D.P.E. Satijn, J.F. Brons, R. van Blokland, P. Kwakman, A.L. Kruckeberg, A. Kelder, A.P. Otte, Identification of anti-repressor elements that confer high and stable protein production in mammalian cells, Nat. Biotech. 21 (2003) 553-558.

[63] Y. Huang, Y. Li, Y.G. Wang, X. Gu, Y. Wang, B.F. Shen, An efficient and targeted gene integration system for high-level antibody expression, J. Immunol. Methods 322 (2007) 28-39.

[64] T.-Y. Wang, R. Yang, C. Qin, L. Wang, X.-J. Yang, Enhanced expression of transgene in $\mathrm{CHO}$ cells using matrix attachment region, Cell Biol. Int. 32 (2008) 1279-1283.

[65] P.-A. Girod, M. Zahn-Zabal, N. Mermod, Use of the chicken lysozyme 5prime matrix attachment region to generate high producer $\mathrm{CHO}$ cell lines, Biotechnol. Bioeng. 91 (2005) 1-11.

[66] C.W. Schweinfest, C.L. Jorcyk, S. Fujiwara, T.S. Papas, A heat-shock-inducible eukaryotic expression vector, Gene 71 (1988) 207-210.

[67] G.T. Yarranton, Inducible vectors for expression in mammalian cells, Curr. Opin. Biotechnol. 3 (1992) 506-511.

[68] D.E. Kamashev, N.G. Esipovaa, K.K. Ebralidseb, A.D. Mirzabekov, Mechanism of Lac repressor switch-off: orientation of the Lac repressor DNA-binding domain is reversed upon inducer binding, FEBS Lett. 375 (1995) 27-30. 
[69] M. Gossen, S. Freundlieb, G. Bender, G. Muller, W. Hillen, H. Bujard, Transcriptional activation by tetracyclines in mammalian cells, Science 268 (1995) 1766-1769.

[70] H. Kaufmann, X. Mazur, R. Marone, J.E. Bailey, M. Fussenegger, Comparative analysis of two controlled proliferative strategies regarding product quality, influence on tetracycline-regulated gene expression and productivity, Biotechnol. Bioeng. 72 (2001) 582-602.

71] M. Fussenegger, R.P. Morris, C. Fux, M. Rimann, B. von Stockar, C.J. Thompson, J.E. Bailey, Streptogramin-based gene regulation systems for mammalian cells, Nat. Biotech. 18 (2000) 1203-1208.

[72] D. No, T.P. Yao, R.M. Evans, Ecdysone-inducible gene expression in mammalian cells and transgenic mice, Proc. Natl. Acad. Sci. USA 93 (1996) 3346-3351.

[73] J. Li, C. Menzel, D. Meier, C. Zhang, S. Dübel, T. Jostock, A comparative study of different vector designs for the mammalian expression of recombinant IgG antibodies, J. Immunol. Methods 318 (2007) 113-124.

[74] S. Schlatter, S.H. Stansfield, D.M. Dinnis, A.J. Racher, J.R. Birch, D.C. James, On the optimal ratio of heavy to light chain genes for efficient recombinant antibody production by CHO cells, Biotechnol. Prog. 21 (2005) 122-133.

[75] K. Leitzgen, M.R. Knittler, I.G. Haas, Assembly of immunoglobulin light chains as a prerequisite for secretion. A model for oligomerization-dependent subunit folding, J. Biol. Chem. 272 (1997) 3117-3123.

[76] M. Fussenegger, J.E. Bailey, H. Hauser, P.P. Mueller, Genetic optimization of recombinant glycoprotein production by mammalian cells, Trends Biotechnol. 17 (1999) 35-42.

[77] P.S. Mountford, A.G. Smith, Internal ribosome entry sites and dicistronic RNAs in mammalian transgenesis, Trends Genet. 11 (1995) 179-184.

[78] H. Kaufmann, M. Fussenegger, Metabolic engineering of mammalian cells for higher protein yield, in: S.C. Makrides (Ed.), Gene Transfer and Expression in Mammalian Cells, Elsevier Science BV, Netherlands, 2003, pp. 457-469.

[79] K. Yahata, H. Kishine, T. Sone, Y. Sasaki, J. Hotta, J.D. Chesnut, M. Okabe, F. Imamoto, Multi-gene gateway clone design for expression of multiple heterologous genes in living cells: conditional gene expression at near physiological levels, J. Biotechnol. 118 (2005) 123-134.

[80] Y.Z. Kunes, W.R. Gion, E. Fung, J.G. Salfeld, R.-R. Zhu, P. Sakorafas, G.R. Carson, Expression of antibodies using single-open reading frame vector design and polyprotein processing from mammalian cells, Biotechnol. Prog. (2009) (available online in advance of print).

[81] P.J. Belshaw, S.N. Ho, G.R. Crabtree, S.L. Schreiber, Controlling protein association and subcellular localization with a synthetic ligand that induces heterodimerization of proteins, Proc. Natl. Acad. Sci. USA 93 (1996) 46044607.

[82] S. Hartenbach, M.D.-E. Baba, W. Weber, M. Fussenegger, An engineered Larginine sensor of Chlamydia pneumoniae enables arginine-adjustable transcription control in mammalian cells and mice, Nucl. Acids Res. (2007) (gkm652).

[83] I. Mijakovic, D. Petranovic, P.R. Jensen, Tunable promoters in systems biology, Curr. Opin. Biotechnol. 16 (2005) 329-335.

[84] H. Alper, C. Fischer, E. Nevoigt, G. Stephanopoulos, Tuning genetic control through promoter engineering, Proc. Natl. Acad. Sci. USA 102 (2005) 1267812683.

[85] G.M. Edelman, R. Meech, G.C. Owens, F.S. Jones, Synthetic promoter elements obtained by nucleotide sequence variation and selection for activity, Proc. Natl. Acad. Sci. USA 97 (2000) 3038-3043.

[86] Y. Yuansheng, Mariati, S.C.L. Ho, M.G.S. Yap, Mutated polyadenylation signals for controlling expression levels of multiple genes in mammalian cells, Biotechnol. Bioeng. 102 (2009) 1152-1160.

[87] M.P. Rosser, W. Xia, S. Hartsell, M. McCaman, Y. Zhu, S. Wang, S. Harvey, P. Bringmann, R.R. Cobb, Transient transfection of CHO-K1-S using serum-free medium in suspension: a rapid mammalian protein expression system, Protein Expr. Purif. 40 (2005) 237-243.

[88] M.M.l. Liao, N.-A. Sunstrom, A transient expression vector for recombinant protein production in Chinese hamster ovary cells, J. Chem. Tech. Biotechnol. 81 (2006) 82-88.

[89] H.D. Blasey, J.-P. Aubry, G.J. Mazzei, A.R. Bernard, Large scale transient expression with COS cells, Cytotechnology 18 (1995) 183-192.

[90] A.K. Preuss, J.A. Connor, H. Vogel, Transient transfection induces different intracellular calcium signaling in CHO K1 versus HEK 293 cells, Cytotechnology 33 (2000) 139-145.

[91] R.J. Kaufman, Amplification and expression of transfected genes in mammalian cells, in: R. Kellems (Ed.), Gene Amplification in Mammalian Cells: A Comprehensive Guide, CRC Press, Boca Raton, FL, 1992, pp. 315343.

[92] J. Chusainow, Y.S. Yang, J.H.M. Yeo, P.C. Toh, P. Asvadi, N.S.C. Wong, M.G.S. Yap, A study of monoclonal antibody-producing CHO cell lines: what makes a stable high producer?, Biotechnol Bioeng. 102 (2009) 1182-1196.

[93] R.J. Kaufman, Selection and coamplification of heterologous genes in mammalian cells, Methods Enzymol. 185 (1990) 537-566.

[94] G.S. Lonza, Gene Expression System, 2009, <http://www.lonza.com/group/en/ products_services/custommanufactoring/mammalian/geneexpressions.html>.

[95] M.I. Cockett, C.R. Bebbington, G.T. Yarranton, High level expression of tissue inhibitor of metalloproteinases in Chinese hamster ovary cells using glutamine synthetase gene amplification, Nat. Biotech. 8 (1990) 662-667.

[96] M. Brown, G. Renner, R. Field, T. Hassell, Process development for the production of recombinant antibodies using the glutamine synthetase (GS) system, Cytotechnology 9 (1992) 231-236.
[97] L.M. Barnes, C.M. Bentley, A.J. Dickson, Characterization of the stability of recombinant protein production in the GS-NSO expression system, Biotechnol. Bioeng. 73 (2001) 261-270.

[98] F.L. Graham, A.J. van der Eb, A new technique for the assay of infectivity of human adenovirus 5 DNA, Virology 52 (1973) 456-467.

[99] O. Boussif, F. Lezoualc'h, M.A. Zanta, M.D. Mergny, D. Scherman, B. Demeneix J.P. Behr, A versatile vector for gene and oligonucleotide transfer into cells in culture and in vivo: polyethylenimine, Proc. Natl. Acad. Sci. USA 92 (1995) 7297-7301.

[100] G. Chu, H. Hayakawa, P. Berg, Electroporation for the efficient transfection of mammalian cells with DNA, Nucl. Acids Res. 15 (1987) 1311-1326.

[101] P.A. Norton, C.J. Pachuk, Methods for DNA introduction into mammalian cells, in: S.C. Makrides (Ed.), Gene Transfer and Expression in Mammalian Cells, Elsevier Science BV, Amsterdam, 2003, pp. 265-277.

[102] M. Jordan, A. Schallhorn, F.M. Wurm, Transfecting mammalian cells: optimization of critical parameters affecting calcium-phosphate precipitate formation, Nucl. Acids Res. 24 (1996) 596-601.

[103] S.P. Wilson, L.A. Smith, Addition of glycerol during DNA exposure enhances calcium phosphate transfection, Anal. Biochem. 246 (1997) 148-150.

104] P. Batard, M. Jordan, F. Wurm, Transfer of high copy number plasmid into mammalian cells by calcium phosphate transfection, Gene 270 (2001) 61-68

[105] S. Chenuet, D. Martinet, N. Besuchet-Schmutz, M. Wicht, N. Jaccard, A.-C. Bon, M. Derouazi, D.L. Hacker, J.S. Beckmann, F.M. Wurm, Calcium phosphate transfection generates mammalian recombinant cell lines with higher specific productivity than polyfection, Biotechnol. Bioeng. 101 (2008) 937945.

[106] P.J. Canatella, J.F. Karr, J.A. Petros, M.R. Prausnitz, Quantitative study of electroporation-mediated molecular uptake and cell viability, Cell 80 (2001) 755-764.

[107] X. Gao, L. Huang, Cationic liposome-mediated gene transfer, Gene Ther. 2 (1995) 710-722.

[108] M. Derouazi, P. Girard, F. Van Tilborgh, K. Iglesias, N. Muller, M. Bertschinger F.M. Wurm, Serum-free large-scale transient transfection of $\mathrm{CHO}$ cells, Biotechnol. Bioeng. 87 (2004) 537-545.

[109] A.S. Tait, C.J. Brown, D.J. Galbraith, M.J. Hines, M. Hoare, J.R. Birch, D.C. James, Transient production of recombinant proteins by Chinese hamster ovary cells using polyethyleneimine/DNA complexes in combination with microtubule disrupting anti-mitotic agents, Biotechnol. Bioeng. 88 (2004) 707-721.

[110] W.T. Godbey, K.K. Wu, A.G. Mikos, Tracking the intracellular path of poly(ethylenimine)/DNA complexes for gene delivery, Proc. Natl. Acad. Sci. USA 96 (1999) 5177-5181.

[111] F. Li, J.X. Zhou, X. Yang, T. Tressel, B. Lee, Current therapeutic antibody production and process optimization, BioProcess. J. 4 (2005).

[112] D.R. Lloyd, P. Holmes, L.P. Jackson, A.N. Emery, M. Al-Rubeai, Relationship between cell size, cell cycle and specific recombinant protein productivity, Cytotechnology 34 (2000) 59-70.

113] E. Böhm, R. Voglauer, W. Steinfellner, R. Kunert, N. Borth, H. Katinger, Screening for improved cell performance: selection of subclones with altered production kinetics or improved stability by cell sorting, Biotechnol. Bioeng 88 (2004) 699-706.

[114] N.S. Kim, S.J. Kim, G.M. Lee, Clonal variability within dihydrofolate reductasemediated gene amplified Chinese hamster ovary cells: stability in the absence of selective pressure, Biotechnol. Bioeng. 60 (1998) 679-688.

[115] M. Rieseberg, C. Kasper, K.F. Reardon, T. Scheper, Flow cytometry in biotechnology, Appl. Microbiol. Biotechnol. 56 (2001) 350-360.

[116] G. Georgiou, B.R. Harvey, K.E. Griswold, B.L. Iverson, Applications of flow cytometry in protein engineering, in: L.A. Sklar (Ed.), Flow Cytometry for Biotechnology, Oxford University Press Inc., New York, 2005, pp. 212-388.

[117] K.T. Powell, J.C. Weaver, Gel microdroplets and flow cytometry: rapid determination of antibody secretion by individual cells within a cell population, Nat. Biotech. 8 (1990) 333-337.

[118] J.C. Weaver, J.G. Bliss, K.T. Powell, G.I. Harrison, G.B. Williams, Rapid clonal growth measurements at the single-cell level: gel microdroplets and flow cytometry, Nat. Biotech. 9 (1991) 873-877.

[119] C. Gandor, C. Leist, A. Fiechter, F.A. Asselbergs, Amplification and expression of recombinant genes in serum-independent Chinese hamster ovary cells, FEBS Lett. 377 (1995) 290-294.

120] C.G. Bailey, A.S. Tait, N.-A. Sunstrom, High-throughput clonal selection of recombinant $\mathrm{CHO}$ cells using a dominant selectable and amplifiable metallothionein-GFP fusion protein, Biotechnol. Bioeng. 80 (2002) 670-676.

121] S. Carroll, M. Al-Rubeai, The selection of high-producing cell lines using flow cytometry and cell sorting, Expert Opin. Biol. Ther. 4 (2004) 1821-1829.

[122] R. Manz, M. Assenmacher, E. Pfluger, S. Miltenyi, A. Radbruch, Analysis and sorting of live cells according to secreted molecules, relocated to a cellsurface affinity matrix, Proc. Natl. Acad. Sci. USA 92 (1995) 1921-1925.

[123] N. Borth, M. Zeyda, R. Kunert, H. Katinger, Efficient selection of highproducing subclones during gene amplification of recombinant Chinese hamster ovary cells by flow cytometry and cell sorting, Biotechnol. Bioeng. 77 (2000) 118

[124] R.J. Sleiman, P.P. Gray, M.N. McCall, J. Codamo, N.-A.S. Sunstrom, Accelerated cell line development using two-color fluorescence activated cell sorting to select highly expressing antibody-producing clones, Biotechnol. Bioeng. 99 (2008) 578-587.

[125] S.S. Choi, W.J. Rhee, E.J. Kim, T.H. Park, Enhancement of recombinant protein production in Chinese hamster ovary cells through anti-apoptosis engineering using 30Kc6 gene, Biotechnol. Bioeng. 95 (2006) 459-467. 
[126] S.C.O. Pak, S.M.N. Hunt, M.W. Bridges, M.J. Sleigh, P.P. Gray, Super-CHO - a cell line capable of autocrine growth under fully defined protein-free conditions, Cytotechnology 22 (1996) 139-146.

[127] B. Rasmussen, R. Davis, J. Thomas, P. Reddy, Isolation, characterization and recombinant protein expression in Veggie-CHO: a serum-free $\mathrm{CHO}$ host cell line, Cytotechnology 28 (1998) 31-42.

[128] R.P. Singh, M. Al Rubeai, C.D. Gregory, A.N. Emery, Cell death in bioreactors: a role for apoptosis, Biotechnol. Bioeng. 44 (1994) 720-726.

[129] S.O. Hwang, G.M. Lee, Nutrient deprivation induces autophagy as well as apoptosis in Chinese hamster ovary cell culture, Biotechnol. Bioeng. 99 (2008) 678-685.

[130] A.J. Mastrangelo, J.M. Hardwick, S. Zou, M.J. Betenbaugh, Part II. Overexpression of bcl-2 family members enhances survival of mammalian cells in response to various culture insults, Biotechnol. Bioeng. 67 (2000) 555-564.

[131] A. Sanfeliu, G. Stephanopoulos, Effect of glutamine limitation on the death of attached Chinese hamster ovary cells, Biotechnol. Bioeng. 64 (1999) 46-53.

[132] B. Figueroa Jr, E. Ailor, D. Osborne, J.M. Hardwick, M. Reff, M.J. Betenbaugh, Enhanced cell culture performance using inducible anti-apoptotic genes E1B$19 \mathrm{~K}$ and Aven in the production of a monoclonal antibody with Chinese hamster ovary cells, Biotechnol. Bioeng. 97 (2007) 877-892.

[133] C. Altamirano, J.J. Cairo, F. Godia, Decoupling cell growth and product formation in Chinese hamster ovary cells through metabolic control, Biotechnol. Bioeng. 76 (2001) 351-360.

[134] A.V. Carvalhal, S.S. Santos, J. Calado, M. Haury, M.J.T. Carrondo, Cell growth arrest by nucleotides, nucleosides and bases as a tool for improved production of recombinant proteins, Biotechnol. Prog. 19 (2003) 69-83.

[135] N.N. Danial, S.J. Korsmeyer, Cell death: critical control points, Cell 116 (2004) 205-219.

[136] H. Meents, B. Enenkel, H.M. Eppenberger, R.G. Werner, M. Fussenegger Impact of coexpression and coamplification of sICAM and antiapoptosis determinants bcl-2/bcl-xL on productivity, cell survival, and mitochondria number in CHO-DG44 grown in suspension and serum-free media, Biotechnol. Bioeng. 80 (2002) 706-716.

[137] N. Ibarra, S. Watanabe, J.-X. Bi, J. Shuttleworth, M. Al-Rubeai, Modulation of cell cycle for enhancement of antibody productivity in perfusion culture of NS0 cells, Biotechnol. Prog. 19 (2003) 224-228.

[138] D. Jung, S. Côté, M. Drouin, C. Simard, R. Lemieux, Inducible expression of Bcl$\mathrm{XL}$ restricts apoptosis resistance to the antibody secretion phase in hybridoma cultures, Biotechnol. Bioeng. 79 (2002) 180-187.

[139] B. Figueroa Jr, S. Chen, G.A. Oyler, J.M. Hardwick, M.J. Betenbaugh, Aven and $\mathrm{Bcl}-\mathrm{xL}$ enhance protection against apoptosis for mammalian cells exposed to various culture conditions, Biotechnol. Bioeng. 85 (2004) 589-600.

[140] T.M. Sauerwald, M.J. Betenbaugh, G.A. Oyler, Inhibiting apoptosis in mammalian cell culture using the caspase inhibitor XIAP and deletion mutants, Biotechnol. Bioeng. 77 (2002) 704-716.

[141] T.M. Sauerwald, G.A. Oyler, M.J. Betenbaugh, Study of caspase inhibitors for limiting death in mammalian cell culture, Biotechnol. Bioeng. 81 (2003) 329340.

[142] S. Mercille, P. Jolicoeur, C. Gervais, D. Paquette, D.D. Mosser, B. Massie, Dosedependent reduction of apoptosis in nutrient-limited cultures of NS/0 myeloma cells transfected with the E1B-19K adenoviral gene, Biotechnol. Bioeng. 63 (1999) 516-528.

[143] J.A. Zanghi, W.A. Renner, J.E. Bailey, M. Fussenegger, The growth factor inhibitor Suramin reduces apoptosis and cell aggregation in protein-free $\mathrm{CHO}$ cell batch cultures, Biotechnol. Prog. 16 (2000) 319-325.

[144] H.K. Oh, M.K. So, J. Yang, H.C. Yoon, J.S. Ahn, J.M. Lee, J.T. Kim, J.U. Yoo, T.H. Byun, Effect of $\mathrm{N}$-acetylcysteine on butyrate-treated Chinese hamster ovary cells to improve the production of recombinant human interferon-beta-1a, Biotechnol. Prog. 21 (2005) 1154-1164.

[145] S.S. Choi, W.J. Rhee, T.H. Park, Beneficial effect of silkworm hemolymph on a CHO cell system: inhibition of apoptosis and increase of EPO production, Biotechnol. Bioeng. 91 (2005) 793-800.

[146] P.A. Saunders, J.A. Cooper, M.M. Roodell, D.A. Schroeder, C.J. Borchert, A.L. Isaacson, M.J. Schendel, K.G. Godfrey, D.R. Cahill, A.M. Walz, R.T. Loegering, H Gaylord, I.J. Woyno, A.E. Kaluyzhny, R.A. Krzyzek, F. Mortari, M. Tsang, C.F. Roff, Quantification of active caspase 3 in apoptotic cells, Anal. Biochem. 284 (2000) 114-124

[147] H.A. Laken, M.W. Leonard, Understanding and modulating apoptosis in industrial cell culture, Curr. Opin. Biotechnol. 12 (2001) 175-179.

[148] C. Yuan, M. Kadiiska, W.E. Achanzar, R.P. Mason, M.P. Waalkes, Possible role of caspase-3 inhibition in cadmium-induced blockage of apoptosis, Toxicol. Appl. Pharmacol. 164 (2000) 321-329.

[149] N.S. Kim, G.M. Lee, Inhibition of sodium butyrate-induced apoptosis in recombinant Chinese hamster ovary cells by constitutively expressing antisense RNA of caspase-3, Biotechnol. Bioeng. 78 (2002) 217-228.

[150] Y.H. Sung, S.-J. Hwanga, G.M. Lee, Influence of down-regulation of caspase-3 by siRNAs on sodium-butyrate-induced apoptotic cell death of Chinese hamster ovary cells producing thrombopoietin, Metab. Eng. 7 (2005) 457466.

[151] Y.H. Sung, J.S. Lee, S.H. Park, J. Koo, G.M. Lee, Influence of co-down-regulation of caspase-3 and caspase-7 by siRNAs on sodium butyrate-induced apoptotic cell death of Chinese hamster ovary cells producing thrombopoietin, Metab. Eng. 9 (2007) 452-464.

[152] R.R. Balcarcel, G. Stephanopoulos, Rapamycin reduces hybridoma cell death and enhances monoclonal antibody production, Biotechnol. Bioeng. 76 (2001) 1-10.
[153] T.I. Linardos, N. Kalogerakis, L.A. Behie, Cell cycle model for growth rate and death rate in continuous suspension hybridoma cultures, Biotechnol. Bioeng. 40 (1992) 359-368.

[154] Y.H. Kim, T. Iida, T. Fujita, S. Terada, A. Kitayama, H. Ueda, E.V. Prochownik, E. Suzuki, Establishment of an apoptosis-resistant and growth-controllable cell line by transfecting with inducible antisense c-Jun gene, Biotechnol. Bioeng. 58 (1998) 65-72.

[155] J.-X. Bi, J. Shuttleworth, M. Al-Rubeai, Uncoupling of cell growth and proliferation results in enhancement of productivity in p21CIP1-arrested CHO cells, Biotechnol. Bioeng. 85 (2004) 741-749.

[156] S. Oguchi, H. Saito, M. Tsukahara, H. Tsumura, pH Condition in temperature shift cultivation enhances cell longevity and specific hMab productivity in CHO culture, Cytotechnology 52 (2006) 199-207.

[157] S. Kim, G. Lee, Functional expression of human pyruvate carboxylase for reduced lactic acid formation of Chinese hamster ovary cells (DG44), Appl. Microbiol. Biotechnol. 76 (2007) 659-665.

[158] S.H. Kim, G.M. Lee, Down-regulation of lactate dehydrogenase-A by siRNAs for reduced lactic acid formation of Chinese hamster ovary cells producing thrombopoietin, Appl. Microbiol. Biotechnol. 74 (2007) 152-159.

[159] H.-S. Park, I.-H. Kim, I.-Y. Kim, K.-H. Kim, H.-J. Kim, Expression of carbamoyl phosphate synthetase I and ornithine transcarbamoylase genes in Chinese hamster ovary dhfr-cells decreases accumulation of ammonium ion in culture media, J. Biotechnol. 81 (2000) 129-140.

[160] S. Reuveny, Y.J. Kim, C.W. Kemp, J. Shiloach, Effect of temperature and oxygen on cell growth and recombinant protein production in insect cell cultures, Appl. Microbiol. Biotechnol. 38 (1993) 619-623.

[161] S.K. Yoon, J.Y. Song, G.M. Lee, Effect of low culture temperature on specific productivity, transcription level, and heterogeneity of erythropoietin in Chinese hamster ovary cells, Biotechnol. Bioeng. 82 (2003) 289-298.

[162] H. Kaufmann, X. Mazur, M. Fussenegger, J.E. Bailey, Influence of low temperature on productivity, proteome and protein phosphorylation of CHO cells, Biotechnol. Bioeng. 63 (1999) 573-582.

[163] S.K. Yoon, S.O. Hwang, G.M. Lee, Enhancing effect of low culture temperature on specific antibody productivity of recombinant Chinese hamster ovary cells: clonal variation, Biotechnol. Prog. 20 (2004) 1683-1688.

[164] M. Bollati-Fogolín, G. Forno, M. Nimtz, H.S. Conradt, M. Etcheverrigaray, R. Kratje, Temperature reduction in cultures of hGM-CSF-expressing CHO cells: effect on productivity and product quality, Biotechnol. Prog. 21 (2005) 17-21.

[165] M.S. Lee, G.M. Lee, Hyperosmotic pressure enhances immunoglobulin transcription rates and secretion rates of KR12H-2 transfectoma, Biotechnol. Bioeng. 68 (2000) 260-268.

[166] J.-W. Bloemkolk, M.R. Gray, F. Merchant, T.R. Mosmann, Effect of temperature on hybridoma cell cycle and MAb production, Biotechnol. Bioeng. 40 (1992) 427-431.

[167] J.K. Hong, Y.-G. Kim, S.K. Yoona, G.M. Lee, Down-regulation of cold-inducible RNA-binding protein does not improve hypothermic growth of Chinese hamster ovary cells producing erythropoietin, Metab. Eng. 9 (2007) 208-216.

[168] V. Hendrick, P. Winnepenninckx, C. Abdelkafi, O. Vandeputte, M. Cherlet, T. Marique, G. Renemann, A. Loa, G. Kretzmer, J. Werenne, Increased productivity of recombinant tissular plasminogen activator (t-PA) by butyrate and shift of temperature: a cell cycle phases analysis, Cytotechnology 36 (2001) 71-83.

[169] S.C.Y. Ku, D.T.W. Ng, M.G.S. Yap, S.-H. Chao, Effects of overexpression of X-box binding protein 1 on recombinant protein production in Chinese hamster ovary and NS0 myeloma cells, Biotechnol. Bioeng. 99 (2008) 155-164.

[170] M. Schröder, The cellular response to protein unfolding stress, in: G.D. Robson, P. van West, G.M. Gadd (Eds.), Exploitation of Fungi, Cambridge University Press, Cambridge, 2007, pp. 117-139.

[171] C. Wilson, H.J. Bellen, W.J. Gehring, Position effects on eukaryotic gene expression, Ann. Rev. Cell Biol. 6 (1990) 679-714.

[172] C.M. Smales, D.M. Dinnis, S.H. Stansfield, D. Alete, E.A. Sage, J.R. Birch, A.J. Racher, C.T. Marshall, D.C. James, Comparative proteomic analysis of GS-NSO murine myeloma cell lines with varying recombinant monoclonal antibody production rate, Biotechnol. Bioeng. 88 (2004) 474-488.

[173] J. Jones, T. Nivitchanyong, C. Giblin, V. Ciccarone, D. Judd, S. Gorfien, S.S. Krag, M.J. Betenbaugh, Optimization of tetracycline-responsive recombinant protein production and effect on cell growth and ER stress in mammalian cells, Biotechnol. Bioeng. 91 (2005) 722-732.

[174] N. Borth, D. Mattnovich, R. Kunert, H. Katinger, Effect of increased expression of protein disulfide isomerase and heavy chain binding protein on antibody secretion in a recombinant $\mathrm{CHO}$ cell line, Biotechnol. Prog. 21 (2005) 106-111.

[175] R. Davis, K. Schooley, B. Rasmussen, J. Thomas, P. Reddy, Effect of PDI overexpression on recombinant protein secretion in $\mathrm{CHO}$ cells, Biotechnol. Prog. 16 (2000) 736-743.

[176] R. Jefferis, Glycosylation of human IgG antibodies: relevance to therapeutic applications, BioPharm Int. 9 (2001) 19-27.

[177] C. Mohan, S.H. Park, J.Y. Chung, G.M. Lee, Effect of doxycycline-regulated protein disulfide isomerase expression on the specific productivity of recombinant $\mathrm{CHO}$ cells: thrombopoietin and antibody, Biotechnol. Bioeng. 98 (2007) 611-615.

[178] A.J. Dorner, M.G. Krane, R.J. Kaufman, Reduction of endogenous GRP78 levels improves secretion of a heterologous protein in $\mathrm{CHO}$ cells, Mol. Cell. Biol. 8 (1988) 4063-4070.

[179] S.O. Hwang, J.Y. Chung, G.M. Lee, Effect of doxycycline-regulated ERp57 expression on specific thrombopoietin productivity of recombinant $\mathrm{CHO}$ cells, Biotechnol. Prog. 19 (2003) 179-184. 
[180] J.Y. Chung, S.W. Lim, Y.J. Hong, S.O. Hwang, G.M. Lee, Effect of doxycyclineregulated calnexin and calreticulin expression on specific thrombopoietin productivity of recombinant Chinese hamster ovary cells, Biotechnol. Bioeng. 85 (2004) 539-546.

[181] E. Grabenhorst, P. Schlenke, S. Pohl, M. Nimtz, H.S. Conradt, Genetic engineering of recombinant glycoproteins and glycosylation pathway in mammalian host cells, Glycoconj. J. 16 (1999) 81-97.

[182] A. Wright, S.L. Morrison, Effect of glycosylation on antibody function: implications for genetic engineering, Trends Biotechnol. 15 (1997) 26-32.

[183] S. Weikert, D. Papac, J. Briggs, D. Cowfer, S. Tom, M. Gawlitzek, J. Lofgren, S. Mehta, V. Chisholm, N. Modi, S. Eppler, K. Carroll, S. Chamow, D. Peers, P. Berman, L. Krummen, Engineering Chinese hamster ovary cells to maximize sialic acid content of recombinant glycoproteins, Nat. Biotech. 17 (1999) 11161121.

[184] J. Davies, L.Y. Jiang, L.-Z. Pan, M.U. LaBarre, D. Andersen, M. Reff, Expression of GnTIII in recombinant anti-CD20 CHO production cell line: expression of antibodies with altered glycoforms leads to an increase in ADCC through higher affinity for FcyRIII, Biotechnol. Bioeng. 74 (2001) 288-294.

[185] L. Monaco, A. Marc, A. Eon-Duval, G. Acerbis, G. Distefano, D. Lamotte, J-M. Engasser, M. Soria, N. Jenkins, Genetic engineering of $\alpha 2,6$-sialyltransferase in recombinant $\mathrm{CHO}$ cells and its effects on the sialylation of recombinant interferon- $\gamma$, Cytotechnology 22 (1996) 197-203.

[186] E. Grabenhorst, A. Hoffmann, M. Nimtz, G. Zettlmeissl, H.S. Conradt, Construction of stable BHK-21 cells coexpressing human secretory glycoproteins and human Gal(beta 1-4)GlcNAc-R alpha 2,6sialyltransferase alpha 2,6-linked NeuAc is preferentially attached to the Gal(beta 1-4)GlcNAc(beta 1-2)Man(alpha 1-3)-branch of diantennary oligosaccharides from secreted recombinant beta-trace protein, Eur. J. Biochem. 232 (1995) 718-725.

[187] A. Natsume, M. Wakitani, N. Yamane-Ohnuki, E. Shoji-Hosaka, R. Niwa, K. Uchida, M. Satoh, K. Shitara, Fucose removal from complex-type oligosaccharide enhances the antibody-dependent cellular cytotoxicity of single-gene-encoded bispecific antibody comprising of two single-chain antibodies linked to the antibody constant region, J. Biochem. 140 (2006) 359-368.

[188] N. Yamane-Ohnuki, S. Kinoshita, I.-U. Miho, M. Kusunoki, S. Iida, R. Nakano, M. Wakitani, R. Niwa, M. Sakurada, K. Uchida, K. Shitara, M. Satoh, Establishment of FUT 8 knockout Chinese hamster ovary cells: an ideal host cell line for producing completely defucosylated antibodies with enhanced antibody-dependent cellular cytotoxicity, Biotechnol. Bioeng. 87 (2004) 614-622.

[189] T. Shinkawa, K. Nakamura, N. Yamane, E. Shoji-Hosaka, Y. Kanda, M. Sakurada, K. Uchida, H. Anazawa, M. Satoh, M. Yamasaki, N. Hanai, K. Shitara, The absence of fucose but not the presence of galactose or bisecting $\mathrm{N}$-acetylglucosamine of human IgG1 complex-type oligosaccharides shows the critical role of enhancing antibody-dependent cellular cytotoxicity, J. Biol. Chem. 278 (2003) 3466-3473.

[190] C. Ferrara, P. Brünker, T. Suter, S. Moser, U. Püntener, P. Umaña, Modulation of therapeutic antibody effector functions by glycosylation engineering: influence of Golgi enzyme localization domain and co-expression of heterologous beta1, 4-N-acetylglucosaminyltransferase III and Golgi alphamannosidase II, Biotechnol. Bioeng. 93 (2006) 851-861.
[191] J.E. Bailey, A. Sburlati, V. Hatzimanikatis, K. Lee, W.A. Renner, P.S. Tsai, Inverse metabolic engineering: a strategy for directed genetic engineering of useful phenotypes, Biotechnol. Bioeng. 79 (2002) 568-579.

[192] D.M. Dinnis, S.H. Stansfield, S. Schlatter, C.M. Smales, D. Alete, J.R. Birch A.J. Racher, C.T. Marshall, L.K. Nielsen, D.C. James, Functional proteomic analysis of GS-NS0 murine myeloma cell lines with varying recombinant monoclonal antibody production rate, Biotechnol. Bioeng. 94 (2006) 830841.

[193] V. Hatzimanikatis, K.H. Lee, Dynamical analysis of gene networks requires both mRNA and protein expression information, Metab. Eng. 1 (1999) 275281.

194] M. Zahn-Zabal, M. Kobr, P.A. Girod, M. Imhof, P. Chatellard, M. de Jesus, F. Wurm, N. Mermod, Development of stable cell lines for production or regulated expression using matrix attachment regions, J. Biotechnol. 87 (2001) 29-42.

[195] R.E. Berson, G. Friederichs, A self-feeding roller bottle for continuous cell culture, Biotechnol. Prog. 24 (2008) 154-157.

[196] H.F.J. Savelkoul, A.C.T.M. Vossen, E.G. Breedland, G.J.M. Tibbe, Semipreparative purification and validation of monoclonal antibodies for immunotherapy in mice, J. Immunol. Methods 172 (1994) 33-42.

197] M.J. Keen, N.T. Rapson, Development of a serum-free culture medium for the large scale production of recombinant protein from a Chinese hamster ovary cell line, Cytotechnology 17 (1995) 153-163.

[198] E. Mariani, A.R. Mariani, M.C. Monaco, E. Lalli, M. Vitale, A. Facchini, Commercial serum-free media: hybridoma growth and monoclonal antibody production, J. Immunol. Methods 145 (1991) 175-183.

[199] P.M. Castro, P.M. Hayter, A.P. Ison, A.T. Bull, Application of a statistical design to the optimization of culture medium for recombinant interferon-gamma production by Chinese hamster ovary cells, Appl. Microbiol. Biotechnol. 38 (1992) 84-90.

[200] R.I. Freshney, Culture of Animal Cells: A Manual of Basic Technique, third ed., Wiley-Liss, Inc., New York, 1994.

[201] G.E. Davis, S.D. Skaper, M. Manthorpe, G. Moonen, S. Varon, Fetal calf serummediated inhibition of neurite growth from ciliary ganglion neurons in vitro, J. Neurosci. Res. 12 (1984) 29-39.

[202] D. Barnes, G. Sato, Serum-free cell culture: a unifying approach, Cell 22 (1980) 649-655.

[203] G.M. Lee, E.J. Kim, N.S. Kim, S.K. Yoon, Y.H. Ahn, J.Y. Song, Development of a serum-free medium for the production of erythropoietin by suspension culture of recombinant Chinese hamster ovary cells using a statistical design, J. Biotechnol. 69 (1999) 85-93.

[204] A. Voigt, F. Zintl, Hybridoma cell growth and anti-neuroblastoma monoclona antibody production in spinner flasks using a protein-free medium with microcarriers, J. Biotechnol. 68 (1999) 213-226.

[205] J. Clark, H. Hirstenstein, C. Gebb, Critical parameters in the microcarrier culture of animal cells, Dev. Biol. Stand. 46 (1980) 117-124.

206] M. Glassy, R. Peters, A. Mikhalev, Growth of human-human hybridomas in serum-free media enhances antibody secretion, In Vitro Cell. Dev. Biol. Plant 23 (1987) 745-749.

[207] M. Butler, N. Huzel, N. Barnabé, Unsaturated fatty acids enhance cell yields and perturb the energy metabolism of an antibody-secreting hybridoma, Biochem. J. 322 (1997) 615-623. 